\title{
Peanut Cultivar Response to Flumioxazin Applied Preemergence and Imazapic Applied Postemergence
}

\author{
W. J. Grichar, ${ }^{1}$ P. A. Dotray, ${ }^{2}$ and M. R. Baring ${ }^{3}$ \\ ${ }^{1}$ Texas A\&M AgriLife Research, 3507 Highway 59E, Beeville, TX 78102, USA \\ ${ }^{2}$ Texas A\&M AgriLife Research and Texas A\&M AgriLife Extension Service, Texas Tech University, Lubbock, TX 79403, USA \\ ${ }^{3}$ Texas A\&M AgriLife Research, Department of Soil and Crop Sciences, College Station 77843, USA
}

Correspondence should be addressed to W. J. Grichar; w-grichar@tamu.edu

Received 7 January 2013; Revised 15 April 2013; Accepted 15 May 2013

Academic Editor: Kassim Al-Khatib

Copyright (C) 2013 W. J. Grichar et al. This is an open access article distributed under the Creative Commons Attribution License, which permits unrestricted use, distribution, and reproduction in any medium, provided the original work is properly cited.

\begin{abstract}
Field studies were conducted during 2009 and 2010 in Texas at Yoakum and Lamesa to determine peanut cultivar response to flumioxazin applied preemergence $\left(0.053,0.107\right.$, and $\left.0.214 \mathrm{~kg} \mathrm{ai} \mathrm{ha}^{-1}\right)$ and imazapic applied postemergence $(0.035,0.071$, and $0.141 \mathrm{~kg} \mathrm{ai} \mathrm{ha}^{-1}$ ). At Yoakum, two cultivars (Tamrun OL01, Tamrun OL07) were evaluated while at Lamesa, four cultivars (FlavorRunner 458, Tamrun OL01, Tamrun OL02, and Tamrun OL07) were evaluated. In 2009, no stunting was noted at Yoakum with any herbicide regardless of cultivar. At Lamesa, FlavorRunner 458 and Tamrun OL01 were stunted at least $6 \%$ with the $0.21 \mathrm{~kg} \mathrm{ha}^{-1}$ rate of flumioxazin and 6 to $17 \%$ with the 0.07 and $0.14 \mathrm{~kg} \mathrm{ha}^{-1}$ rate of imazapic. Tamrun OL02 was stunted by all rates of flumioxazin (5\%) and imazapic (5 to 18\%) while Tamrun OL07 was stunted by all rates of flumioxazin (6 to $12 \%$ ) and imazapic ( 7 to $15 \%$ ) with the exception of flumioxazin at $0.05 \mathrm{~kg} \mathrm{ha}^{-1}$. Flumioxazin did not have an effect on yield while all imazapic rates reduced yields when compared with the non-treated control. In 2010 at Yoakum, little $(<2 \%)$ or no herbicide stunting was noted on any cultivar and only imazapic at $0.14 \mathrm{~kg} \mathrm{ha}^{-1}$ caused significant stunting (7\%). No yield differences were noted between herbicides regardless of cultivar. At Lamesa, all cultivars were affected (6 to $9 \%$ stunting) by herbicide treatments. No peanut stunting was noted with flumioxazin at $0.05 \mathrm{~kg} \mathrm{ha}^{-1}$ while imazapic at $0.04 \mathrm{~kg} \mathrm{ha}^{-1}$ and flumioxazin at $0.11 \mathrm{~kg} \mathrm{ha}^{-1}$ resulted in 4 and $6 \%$ stunting, respectively. Flumioxazin at $0.21 \mathrm{~kg} \mathrm{ha}^{-1}$ and imazapic at $0.07 \mathrm{~kg} \mathrm{ha}^{-1}$ resulted in $12 \%$ stunting and imazapic at $0.14 \mathrm{~kg} \mathrm{ha} \mathrm{g}^{-1}$ stunted peanut 19\%. Both Tamrun OL01 and Tamrun OL07 produced lower yields $\left(\leq 6369 \mathrm{~kg} \mathrm{ha}^{-1}\right)$ than FlavorRunner $458\left(7252 \mathrm{~kg} \mathrm{ha}{ }^{-1}\right)$. Tamrun OL02 yields were intermediate $\left(6889 \mathrm{~kg} \mathrm{ha}^{-1}\right)$. Peanut yields from herbicide treatments were not different from the nontreated control.
\end{abstract}

\section{Introduction}

Flumioxazin is an $N$-phenyl phthalamide soil-applied herbicide that received a federal label in the US for use in peanut in 2001 [1]. Flumioxazin inhibits the enzyme protoporphyrinogen oxidase [2-4]. In Georgia, flumioxazin applied preemergence (PRE) was shown to control morningglory species (Ipomoea spp.), prickly sida (Sida spinosa L.), and Florida beggarweed (Desmodium tortuosum (Sw.) DC) [5] while in Texas, pitted morningglory (Ipomoea lacunose L.) was controlled greater than $75 \%$ [6]. Also, flumioxazin is used in the Virginia-Carolina area for early-season suppression of Palmer amaranth (Amaranthus palmeri S. Wats.) and other broadleaf weeds (D. Jordan, personal communication).
Imazapic is similar to imazethapyr and controls all the weeds controlled by imazethapyr [7-13]. In addition, imazapic provides control and suppression of Florida beggarweed and sicklepod (Senna obtusifolia (L.) Irwin \& Barneby), which are not adequately controlled by imazethapyr [12]. Imazethapyr provides consistent control of many broadleaf and sedge species (Cyperus spp.) if applied within $10 \mathrm{~d}$ after emergence, but imazapic has a longer effectiveness period when applied postemergence (POST) $[9,11,14,15]$. Imazapic also is effective control of rhizome and seedling johnsongrass (Sorghum halepense (L.) Pers.), Texas panicum (Panicum texanum Buckl.), large crabgrass (Digitaria sanguinalis (L.) Scop.), southern crabgrass (Digitaria ciliaris (Retz.) Koel.), and broadleaf signalgrass (Brachiaria platyphylla (Griseb.) Nash) [9]. 
Flumioxazin has been reported to cause peanut injury while imazapic has only caused minor stunting [16]. Grichar et al. [1] reported that flumioxazin plus metolachlor combinations, under cool, wet conditions resulted in peanut stunting which was evident throughout the growing season. They attributed this to increased uptake of flumioxazin and metolachlor with the heavy rainfall and the slowed metabolism of these herbicides as a result of cool temperatures [2]. Askew et al. [17] reported that flumioxazin at 0.07 and $0.11 \mathrm{~kg}$ ai ha ${ }^{-1}$ injured peanut 45 and $62 \%$, respectively, when rated 2 weeks after peanut planting. Peanut stunting of greater than $60 \%$ was followed by as much as 35\% leaflet discoloration, which was characterized as necrotic spots on foliage. Scott et al. [18] reported that flumioxazin treated peanuts were injured $10 \%$ when rated 3 weeks after planting. However, injury was transient and was not apparent 6 weeks after planting. Flumioxazin enters plants mainly by shoot and root uptake, and plant injury can be avoided via rapid metabolism $[2,3]$.

Peanut injury from imazapic was observed in North Carolina [19] and from soil applications in south Texas [12] but no injury was observed in other studies $[6,8,12,15,20]$. No reductions in peanut grade or yield following imazapic treatments have been observed in several studies [19, 21-23]. Dotray et al. [23] concluded that peanut injury observed in season does not appear to have any influence on grade or yield.

Many peanut cultivars now used in the southwest production area have not been evaluated with respect to response to flumioxazin or imazapic. Therefore, the objective of this research was to evaluate the effect of flumioxazin applied preemergence or imazapic applied postemergence on peanut growth and yield of four runner market-type peanut cultivars.

\section{Materials and Methods}

2.1. Research Sites. Peanut tolerance studies, under weed-free conditions, were conducted in south Texas near Yoakum and in the Texas High Plains near Lamesa with runner markettypes during the 2009 and 2010 growing seasons. Soils at Yoakum were a Denhawken sandy clay loam (fine, smectitic, hyperthermic, Vertic Haplustepts, $1.6 \%$ organic matter, $\mathrm{pH}$ 7.6) while soils at Lamesa were an Amarillo fine sandy loam (fine-loamy, mixed, superactive, thermic Aridic Paleustalf, $0.4 \%$ organic matter, $\mathrm{pH} 7.8$ ). Planting dates were July 1, 2009 and May 27, 2010 in south Texas and April 30, 2009 and April 28, 2010 at the High Plains location.

2.2. Peanut Cultivars and Herbicide Treatments. Treatments consisted of a factorial arrangement of two runner markettype peanut varieties in south Texas, Tamrun OL01 [24] and Tamrun OL07 [25] or four varieties at the High Plains location FlavorRunner 458 (a runner-type released by Mycogen Co.) [26], Tamrun OL01, Tamrun OL02 [27], and Tamrun OL07 with six herbicide treatments (flumioxazin at 0.053 , 0.107 , and $0.214 \mathrm{~kg} \mathrm{ha}^{-1}$ and imazapic at $0.035,0.071$, and $\left.0.141 \mathrm{~kg} \mathrm{ha}^{-1}\right)$. This represents $0.5,1.0$, and 2 times the US labeled rate of either herbicide [28, 29].
A non-treated control was included in each study at both locations. At least $12.5 \mathrm{~mm}$ of overhead irrigation was applied to activate the herbicide at Lamesa after peanuts were planted and flumioxazin was applied. Each study was replicated three times. Imazapic treatments include Induce (Helena Chemical Company, Collierville, TN, USA) at $0.25 \%$ v/v at the south Texas location or Agridex (Helena Chemical Company, Memphis, TN, USA) at $2.3 \mathrm{~L} \mathrm{ha}^{-1}$ at the High Plains location. Imazapic POST applications were made approximately five weeks after planting at Lamesa and four weeks after planting at Yoakum.

2.3. Plot Description and Rainfall. Individual plot size was 1.9 by $7.6 \mathrm{~m}$ at Yoakum and 2.1 by $9.5 \mathrm{~m}$ at Lamesa. Rainfall for Lamesa can be best described as average for 2009 and above average for 2010 (Table 1). In 2009, rainfall for April and May was below average but above average for June and July. The rest of the growing season experienced below average rainfall with less than $24 \mathrm{~mm}$ of rainfall for either August, September, or October. In 2010, the growing season was considered wet with above normal rainfall for April, July, and September, with slightly below average rainfall for May and June; however, no rain was received in August and little rain in October. Seasonal rainfall at Yoakum was above normal in both years (Table 1). Rainfall in 2009 was below normal for May through August with near normal rainfall for September and above normal for October. Peanuts were dug in October but due to the exceptional high rainfall throughout the month, peanuts could not be combined. In 2010, rainfall was slightly above normal for May and August and above normal rainfall for July and September. No rainfall was received in October.

Supplemental irrigation was supplied as needed at both locations. Traditional production practices were used to maximize peanut growth, development, and yield. All plots received a dinitroaniline herbicide applied preplant incorporated and were cultivated and hand-weeded throughout the growing season to maintain weed-free conditions. Clethodim at $0.18 \mathrm{~kg}$ ai ha ${ }^{-1}$ was applied POST to control annual grass escapes at the south Texas location. No insecticides were needed at any location in any year.

2.4. Herbicide Application and Peanut Response. Herbicides were applied using water as a carrier with a $\mathrm{CO}_{2}$-pressurized backpack sprayer using TeeJet 11002 DG flat fan nozzles (TeeJet Spraying Systems Co., Wheaton, IL, USA) that delivered $190 \mathrm{~L} \mathrm{ha}^{-1}$ at $180 \mathrm{kPa}$ at Yoakum or Turbo TeeJet 110015 flat fan nozzles that delivered $140 \mathrm{~L} \mathrm{ha}^{-1}$ at $207 \mathrm{kPa}$ at Lamesa. Peanut stunting was rated approximately $60 \mathrm{~d}$ after peanut planting with the runner peanuts cultivars in south Texas and the High Plains area. Peanut stunting was based on a scale of 0 to $100(0=$ no peanut stunting) to 100 (peanut death). Peanut yield was determined by digging the pods based on maturity of non-treated control plots, air-drying in the field for 6 to $10 \mathrm{~d}$, and harvesting individual plots with a combine. Yield samples were cleaned and adjusted to $10 \%$ moisture. For grades, a $200 \mathrm{~g}$ pod sample from each plot was obtained 
TABLE 1: Rainfall amounts at Lamesa and Yoakum during the 2009 and 2010 growing seasons.

\begin{tabular}{lcccccc}
\hline \multirow{2}{*}{ Month } & \multicolumn{3}{c}{ Lamesa } & \multicolumn{3}{c}{ Yoakum } \\
& 2009 & 2010 & $60 \mathrm{yr}$ avg & 2009 & 2010 & $30 \mathrm{yr}$ avg \\
\hline \multirow{3}{*}{ April } & 12.7 & 88.9 & 35.8 & 222.5 & 36.1 & 81.0 \\
May & 35.1 & 35.1 & 58.4 & 16.3 & 118.4 & 110.2 \\
June & 158.0 & 72.4 & 77.2 & 3.8 & 95.0 & 105.9 \\
July & 125.5 & 199.4 & 48.5 & 5.3 & 200.7 & 71.6 \\
August & 12.7 & 0 & 48.5 & 42.7 & 89.4 & 75.4 \\
September & 23.1 & 134.6 & 63.8 & 114.1 & 223.3 & 102.6 \\
October & 22.4 & 7.6 & 49.0 & 352.6 & 0 & 83.8 \\
\hline Total & 389.5 & 538.0 & 381.2 & 757.3 & 762.9 & 630.5 \\
\hline
\end{tabular}

and grades determined following procedures described by the Federal-State Inspection Service [30].

2.5. Data Analysis. Data for percentage of peanut injury and stunting were transformed to the arcsine square root prior to analysis; however, nontransformed means are presented because arscine transformation did not affect interpretation of this data. Data were subjected to ANOVA and analyzed using SAS PROC MIXED with locations and years designated as random effects in the model [31]. Treatment means were separated using Fisher's Protected LSD at $P \leq 0.05$. The nontreated control was used for peanut yield and grade calculation comparison and a visual comparison for peanut injury and was only included in yield and grade analysis.

\section{Results}

Peanut was planted at Yoakum in 2009 and peanut growth response was observed and recorded. However, extremely wet conditions persisted for approximately 4 weeks after the peanuts were dug which prevented entry into the field in time to harvest in a timely manner; therefore, yield data was collected only in 2010. Yield data was collected at Lamesa in both years.

3.1. Peanut Stunting. No peanut stunting was observed at Yoakum in 2009 (data not shown). There was a herbicide treatment by peanut cultivar interaction at Lamesa in 2009 (Table 2) while at Lamesa and Yoakum in 2010, peanut cultivar and herbicide treatment were significant (Table 3). In 2009 at Lamesa, flumioxazin at $0.053 \mathrm{~kg} \mathrm{ha}^{-1}$ caused stunting only on Tamrun OL02 (5\%) while flumioxazin at $0.107 \mathrm{~kg} \mathrm{ha}^{-1}$ caused stunting on Tamrun OL02 and Tamrun OL07 (5 to 6\%) and flumioxazin at $0.214 \mathrm{~kg} \mathrm{ha}^{-1}$ caused at least $5 \%$ stunting on all four peanut cultivars (Table 2). Also, imazapic at $0.035 \mathrm{~kg} \mathrm{ha}^{-1}$ caused at least $5 \%$ stunting on Tamrun OL02 and Tamrun OL07 while imazapic at $0.071 \mathrm{~kg} \mathrm{ha}^{-1}$ (6 to $10 \%$ ) and $0.141 \mathrm{~kg} \mathrm{ha}^{-1}$ (13 to $18 \%$ ) stunted all four peanut cultivars.

In 2010 herbicide and rate did have an effect on peanut growth at both locations. At Yoakum, Tamrun OL01 and
Tamrun OL07 responded similarly to both herbicides while at Lamesa all peanut cultivars resulted in stunting from the application of flumioxazin and imazapic (Table 3). Stunting was greatest with Tamrun OL02 (9\%) while FlavorRunner 458 showed the least stunting (6\%). At Yoakum, stunting was greatest $(7 \%)$ with imazapic at $0.141 \mathrm{~kg} \mathrm{ha}^{-1}$ with all other rates of imazapic and all flumioxazin rates showing $3 \%$ or less stunting (Table 3). At Lamesa, all rates of flumioxazin, with the exception of flumioxazin at $0.053 \mathrm{~kg} \mathrm{ha}^{-1}$, resulted in at least $6 \%$ peanut stunting while all rates of imazapic resulted in at least $4 \%$ peanut stunting. With both herbicides, peanut stunting increased as the herbicide rate increased.

Previous research has reported a reduction in peanut canopy development in some instances when flumioxazin has been used followed by cool, wet conditions $[1,32]$. Vencill [33] found that if peanut germinated in above normal concentrations of flumioxazin due to soils with little subsoil moisture receiving water, injury occurred. Conversely, the use of imazapic has also been mentioned as having an effect on peanut canopy [23]. However, earlier work with Runner, Spanish, and Virginia peanut market types reported, regardless of application timing (ground cracking to $56 \mathrm{~d}$ after ground cracking), that imazapic at $0.07 \mathrm{~kg} \mathrm{ha}^{-1}$ did not affect canopy height or width $[20,23]$.

3.2. Peanut Yield. At Lamesa, there was a herbicide and rate effect in 2009 while in 2010 there was a cultivar response but no herbicide and rate effect. In 2010 at Yoakum, there was no peanut cultivar or herbicide and rate response (Table 4).

In 2009 at Lamesa, no difference in peanut yield was noted between the non-treated control and any flumioxazin rate while all imazapic rates reduced yield when compared with the non-treated control (Table 4). In 2010 at Yoakum, no peanut cultivar or herbicide and rate effect were noted and at Lamesa there was only a peanut cultivar response. Both Tamrun OL01 and Tamrun OL07 resulted in lower yields than FlavorRunner 458 (Table 4).

\section{Discussion}

Other studies have reported that flumioxazin had no influence on the yield of various peanut cultivars $[17,32]$ although cool, wet conditions may result in some peanut stunting $[1,17$, 34]. Main et al. [32] reported that yields of Georgia Green, C99R, or MDR-98 were not influenced by flumioxazin applied at the US labeled rate. In another study, Wilcut et al. [34] showed that flumioxazin did not affect the yield of eight Virginia-type cultivars.

Imazapic has had no effect on peanut cultivar yield in other studies $[20,34]$. Also, in weed efficacy studies, no reductions in peanut grade or yield have been observed with imazapic [11, 19, 21, 22]. However, the reduced yields with imazapic observed at Lamesa in 2009 may be attributed to several factors. Most peanut soils in south Texas have a $\mathrm{pH}$ of 6.5 to 7.5 and organic matter contents less than $1 \%$. Therefore, in these soils, imidazolinone herbicides are readily available for microbial degradation [35]. However, in the Texas High Plains, the $\mathrm{pH}$ may range from 7.0 to 8.5 resulting in reduced 
TABLE 2: Response of peanut cultivars to flumioxazin and imazapic in 2009 at Lamesa when rated 4 weeks after postemergence application.

\begin{tabular}{|c|c|c|c|c|c|c|}
\hline \multirow{2}{*}{ Treatment } & \multirow{2}{*}{ Rate } & \multirow{2}{*}{ Application timing } & \multicolumn{4}{|c|}{ Stunting } \\
\hline & & & FL $458^{\mathrm{b}}$ & OL01 & OL02 & OL07 \\
\hline & $\mathrm{Kg}$ ai ha $^{-1}$ & & \multicolumn{4}{|c|}{$\%$} \\
\hline Untreated & - & - & 0 & 0 & 0 & 0 \\
\hline Flumioxazin & 0.053 & PRE & 0 & 0 & 5 & 0 \\
\hline Flumioxazin & 0.107 & PRE & 2 & 2 & 5 & 6 \\
\hline Flumioxazin & 0.214 & PRE & 7 & 6 & 5 & 12 \\
\hline Imazapic & 0.035 & POST & 0 & 3 & 5 & 7 \\
\hline Imazapic & 0.071 & POST & 6 & 10 & 7 & 6 \\
\hline Imazapic & 0.141 & POST & 17 & 13 & 18 & 15 \\
\hline LSD (0.05) & & & \multicolumn{4}{|c|}{4} \\
\hline
\end{tabular}

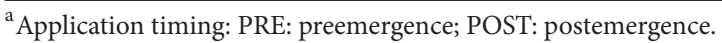

${ }^{\mathrm{b}}$ Peanut cultivars: FL 458: FlavorRunner 458; OL01: Tamrun OL01; OL02: Tamrun OL02; OL07: Tamrun OL07.

TABLE 3: Response of peanut cultivars to flumioxazin and imazapic in 2010 at Yoakum and Lamesa when rated 4 wks after postemergence application.

\begin{tabular}{lcc}
\hline & Yoakum & Lamesa \\
& \multicolumn{2}{c}{ Stunting (\%) } \\
\hline Cultivar & - & 6 \\
$\quad$ FlavorRunner 458 & 2 & 8 \\
Tamrun OL01 & - & 9 \\
Tamrun OL02 & 1 & 8 \\
Tamrun OL07 & $\mathrm{NS}$ & 1 \\
LSD (0.05) & & \\
Herbicide and rate & 0 & 0 \\
non-treated & 1 & 2 \\
Flumioxazin $0.053 \mathrm{~kg} \mathrm{ha}^{-1}$ & 1 & 6 \\
Flumioxazin $0.107 \mathrm{~kg} \mathrm{ha}^{-1}$ & 3 & 12 \\
Flumioxazin $0.214 \mathrm{~kg} \mathrm{ha}^{-1}$ & 2 & 4 \\
Imazapic $0.035 \mathrm{~kg} \mathrm{ha}^{-1}$ & 2 & 12 \\
Imazapic $0.071 \mathrm{~kg} \mathrm{ha}^{-1}$ & 7 & 3 \\
Imazapic $0.141 \mathrm{~kg} \mathrm{ha}^{-1}$ & 4 & \\
LSD (0.05) & &
\end{tabular}

microbial degradation. With soils low in organic matter and near neutral $\mathrm{pH}$, little of the imidazolinone herbicide should be adsorbed on soil particles [35]. Therefore, under certain conditions, more imazapic may have been adsorbed by the peanut cultivars themselves (author's personal opinion).

\section{Conflict of Interests}

The authors declare that they have no conflict of interests.

\section{Acknowledgments}

The authors wish to thank the Texas Peanut Producers Board for helping to fund this research. They also thank Kevin
TABLE 4: Effect of peanut cultivar and herbicide on yield.

\begin{tabular}{lccc}
\hline \multirow{2}{*}{ Treatment } & 2009 & \multicolumn{2}{c}{2010} \\
& Lamesa & Yoakum & Lamesa \\
\hline Cultivar & & $\mathrm{Kg} \mathrm{ha}^{-1}$ & \\
$\quad$ FlavorRunner 458 & 3694 & - & 7252 \\
Tamrun OL01 & 3430 & 2977 & 6352 \\
Tamrun OL02 & 3392 & - & 6889 \\
Tamrun OL07 & 3110 & 2993 & 6369 \\
LSD (0.05) & $\mathrm{NS}$ & $\mathrm{NS}$ & 761 \\
Herbicide and rate & & & \\
non-treated & 3660 & 3110 & 6710 \\
Flumioxazin 0.053 kg ha & 3300 & 3110 & 6950 \\
Flumioxazin 0.107 kg ha & 3600 & 3160 & 6630 \\
Flumioxazin $0.214 \mathrm{~kg} \mathrm{ha}^{-1}$ & 3660 & 3100 & 6700 \\
Imazapic 0.035 kg ha & 3260 & 3120 & 6750 \\
Imazapic $0.071 \mathrm{~kg} \mathrm{ha}^{-1}$ & 3250 & 3130 & 6470 \\
Imazapic 0.141 kg ha & 3120 & 2960 & 6810 \\
LSD (0.05) & 370 & $\mathrm{NS}$ & $\mathrm{NS}$ \\
\hline
\end{tabular}

Brewer, Dwayne Drozd, Lyndell Gilbert, and Bill Klesel for their technical assistance.

\section{References}

[1] W. J. Grichar, B. A. Besler, P. A. Dotray, W. C. Johnson III, and E. P. Prostko, "Interaction of flumioxazin with dimethenamid or metolachlor in peanut (Arachis hypogaea L.)," Peanut Science, vol. 31, no. 1, pp. 12-16, 2004.

[2] R. M. Yoshida, R. Sakaki, R. Sato et al., "S-53482-a new Nphenyl phthalimide herbicide," in Proceedings Brighton Crop Protection Conference, vol. 1, pp. 69-75, Weeds, 1991.

[3] R. J. Anderson, A. E. Norris, and F. D. Hess, "Synthetic organic chemicals that act through the prophyrin pathway," in Porphyric Pesticides: Chemistry, Toxicity, and Pharmaceutical Applications, S. O. Duke and C. A. Rebeiz, Eds., ACS Symposium Series 559, 
pp. 18-33, American Chemical Society, Washington, DC, USA, 1994.

[4] S. A. Senseman, Herbicide Handbook, Weed Science Society of America, Lawrence, Kan, USA, 9th edition, 2007.

[5] J. W. Wilcut, "Summary of flumioxazin performance in southeastern peanuts," in Proceedings of the 50th Annual Meeting of the Southern Weed Science Society (SWSS '97), vol. 50, pp. 1-7, Southern Weed Science Society, 1997.

[6] W. J. Grichar and A. E. Colburn, "Flumioxazin for weed control in Texas peanuts (Arachis hypogaea L.)," Peanut Science, vol. 23, no. 1, pp. 30-36, 1996.

[7] P. R. Nester and W. J. Grichar, "Cadre combinations for broadleaf weeds control in peanut," in Proceedings of the Annual Meeting of the Southern Weed Science Society (SWSS '93), vol. 46, 1993.

[8] W. J. Grichar, A. E. Colburn, and P. R. Nester, "Weed control in Texas peanut with Cadre," in Proceedings of the American Peanut Research and Education Society, vol. 26, p. 70, 1994.

[9] J. W. Wilcut, E. F. Eastin, J. S. Richburg III, W. K. Vencill, F. R. Wells, and G. Wiley, "Imidazolinone systems for southern weed management in resistant corn," Weed Science Society America, vol. 33, article 5, 1993.

[10] J. W. Wilcut, J. S. Richburg III, G. Wiley, F. R. Walls Jr., S. R. Jones, and M. J. Iverson, "Imidazolinone herbicide systems for peanut (Arachis hypogaea L.)," Peanut Science, vol. 21, no. 1, pp. 23-28, 1994.

[11] J. W. Wilcut, A. C. York, W. J. Grichar, and G. R. Wehtje, "The biology and management of weeds in peanut (Arachis hypogaea)," in Advances in Peanut Science, H. E. Pattee and H. T. Stalker, Eds., pp. 207-244, American Peanut Research Education Society, Stillwater, Okla, USA, 1995.

[12] W. J. Grichar and P. R. Nester, "Nutsedge (Cyperus spp.) control in peanut (Arachis hypogaea) with AC 263,222 and imazethapyr," Weed Technology, vol. 11, no. 4, pp. 714-719, 1997.

[13] T. L. Grey, D. C. Bridges, E. F. Eastin et al., "Residual weed control for peanut (Arachis hypogaea) with imazapic, diclosulam, flumioxazin, and sulfentrazone in Alabama, Georgia, and Florida: a multi-state and year summary," in Proceedings of the Meeting of the American Peanut Research and Education Society, vol. 33, p. 19, Oklahoma, Okla, USA, 2001.

[14] J. S. Richburg III, J. W. Wilcut, and G. R. Wehtje, “Toxicity of AC 263,222 to purple (Cyperus rotundus) and yellow nutsedge (C. esculentus)," Weed Science, vol. 42, no. 3, pp. 398-402, 1994.

[15] J. S. Richburg III, J. W. Wilcut, D. L. Colvin, and G. R. Wiley, "Weed management in southeastern peanut (Arachis hypogaea) with AC 263,222," Weed Technology, vol. 10, no. 1, pp. 145-152, 1996.

[16] J. T. Ducar, S. B. Clewis, J. W. Wilcut et al., "Weed management using reduced rate combinations of diclosulam, flumioxazin, and imazapic in peanut," Weed Technology, vol. 23, no. 2, pp. 236-242, 2009.

[17] S. D. Askew, J. W. Wilcut, and J. R. Cranmer, "Weed management in peanut (Arachis hypogaea) with flumioxazin preemergence," Weed Technology, vol. 13, no. 3, pp. 594-598, 1999.

[18] G. H. Scott, S. D. Askew, and J. W. Wilcut, "Economic evaluation of diclosulam and flumioxazin systems in peanut (Arachis hypogaea)," Weed Technology, vol. 15, no. 2, pp. 360-364, 2001.

[19] J. W. Wilcut, J. S. Richburg III, G. L. Wiley, and F. R. Walls Jr., "Postemergence AC 263,222 systems for weed control in peanut (Arachis hypogaea)," Weed Science, vol. 44, no. 3, pp. 615-621, 1996.
[20] J. S. Richburg III, J. W. Wilcut, A. K. Culbreath, and C. K. Kvien, "Response of eight peanut (Arachis hypogaea L.) cultivars to the herbicide AC 263,222," Peanut Science, vol. 22, no. 1, pp. 76-80, 1995.

[21] W. J. Grichar, "Control of palmer amaranth (Amaranthus palmeri) in peanut (Arachis hypogaea) with postemergence herbicides," Weed Technology, vol. 11, no. 4, pp. 739-743, 1997.

[22] T. M. Webster, J. W. Wilcut, and H. D. Coble, "Influence of AC 263,222 rate and application method on weed management in peanut (Arachis hypogaea)," Weed Technology, vol. 11, no. 3, pp. 520-526, 1997.

[23] P. A. Dotray, T. A. Baughman, J. W. Keeling, W. J. Grichar, and R. G. Lemon, "Effect of imazapic application timing on texas peanut (Arachis hypogaea)," Weed Technology, vol. 15, no. 1, pp. 26-29, 2001.

[24] C. E. Simpson, M. R. Baring, A. M. Schubert et al., "Registration of 'Tamrun OL01' peanut," Crop Science, vol. 43, article 2298, 2003.

[25] M. R. Baring, C. E. Simpson, M. D. Burow et al., "Registration of 'Tamrun OL07' peanut," Crop Science, vol. 46, no. 6, pp. 27212722, 2006.

[26] J. Beasley and J. Baldwin, "Peanut cultivars and descriptions," March 2011, http://www.caes.uga.edu/commodities/fieldcrops/ peanuts/production/cultivardescription.html.

[27] C. E. Simpson, M. R. Baring, A. M. Schubert, M. C. Black, H. A. Melouk, and Y. Lopez, "Registration of 'Tamrun OL 02' peanut," Crop Science, vol. 46, pp. 1813-1814, 2006.

[28] Anonymous, Label and MSDS for Valor Herbicide, EPA Registration Number 59639-99, Valent USA Corporation, Walnut Creek, Calif, USA, 2011.

[29] Anonymous, Imazapic Herbicide Label, EPA Registration Number 241-381, BASF, Research Triangle Park, NC, USA, 2011.

[30] USDA, Farmers Stock Peanut Inspection Instructions, Agricultural Marketing Service, Washington, DC, USA, 2008.

[31] Statistical Analysis Systems, SAS User's Guide, version 9.1, SAS Institute, Cary, NC, USA, 2005.

[32] C. L. Main, J. T. Ducar, E. B. Whitty, and G. E. MacDonald, "Response of three runner-type peanut cultivars to flumioxazin," Weed Technology, vol. 17, no. 1, pp. 89-93, 2003.

[33] W. K. Vencill, "Flumioxazin injury to peanut," in Proceedings of the Annual Meeting of the Southern Weed Science Society (SWSS '02), vol. 55, pp. 195-196, 2002.

[34] J. W. Wilcut, S. D. Askew, W. A. Bailey, J. F. Spears, and T. G. Isleib, "Virginia market-type peanut (Arachis hypogaea) cultivar tolerance and yield response to flumioxazin preemergence," Weed Technology, vol. 15, no. 1, pp. 137-140, 2001.

[35] G. Mangels, "Behavior of the imidazolinone herbicide in soil-a review of the literature," in The Imidazolinone Herbicides, D. L. Shaner and S. L. O'Connor, Eds., pp. 191-209, CRC Press, Boca Raton, Fla, USA, 1991. 


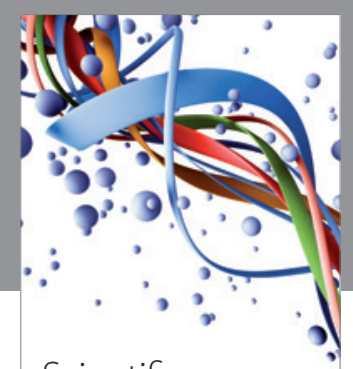

Scientifica
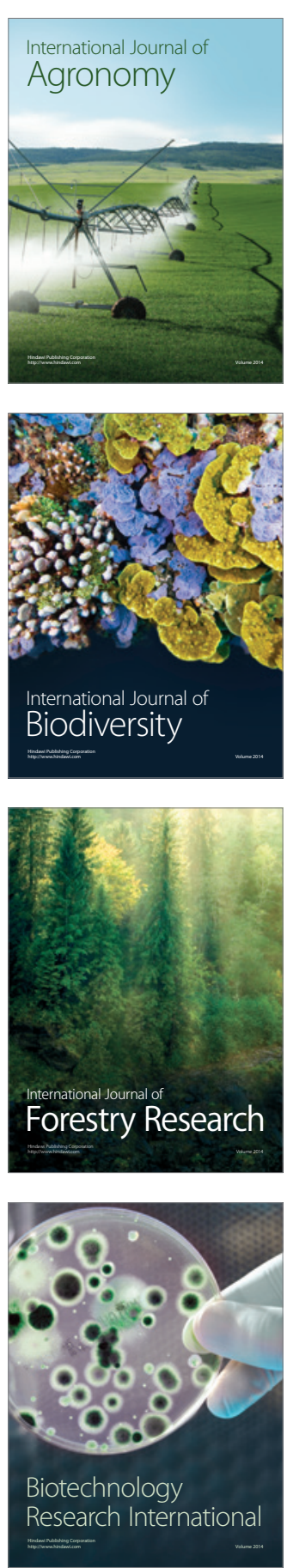
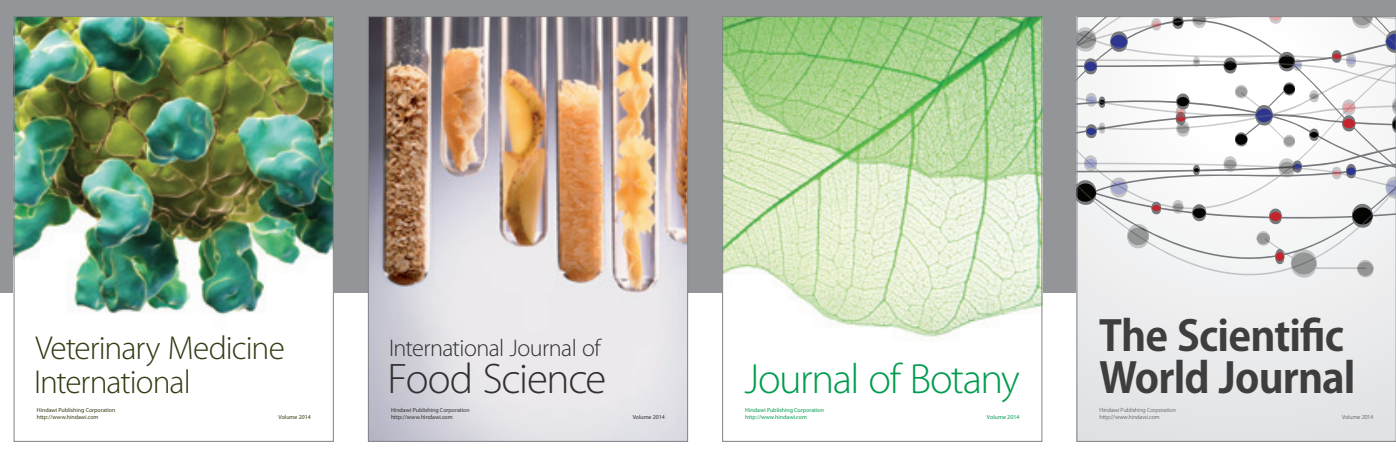

The Scientific World Journal
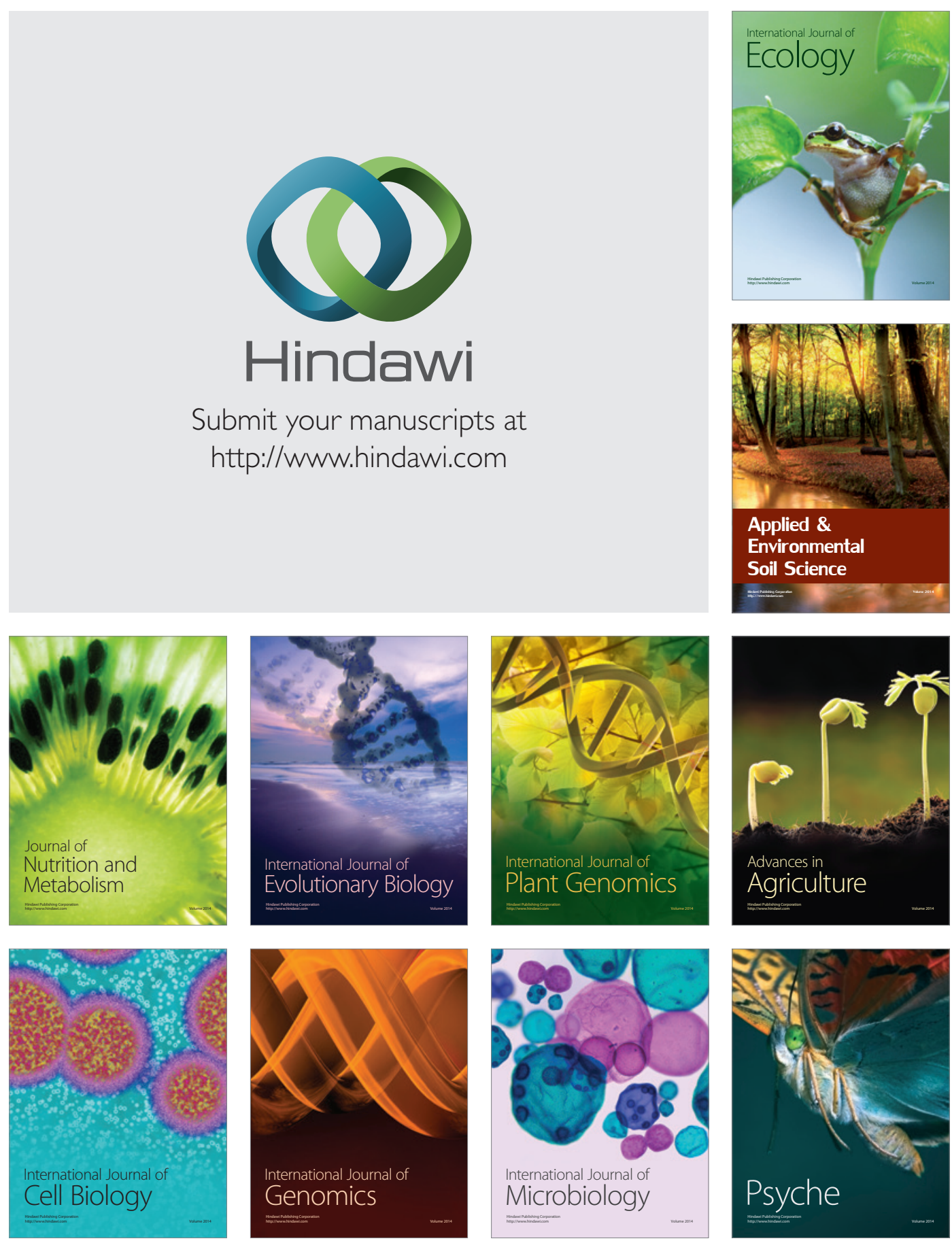